\title{
DURABILITY OF NEW CEMENTS ADDITIONED WITH RECYCLED BIOMASS BOTTOM ASH FROM ELECTRIC POWER PLANTS
}

\author{
J. Medina $^{1^{*}}$, I.F. Sáez del Bosque ${ }^{1}$, M. Frías ${ }^{2}$, M.I. Sánchez de Rojas ${ }^{2}$, C. Medina ${ }^{1^{* *}}$ \\ 1. Departamento de Construcción, Escuela Politécnica de Cáceres - Grado de Ingeniería Civil, \\ Universidad de Extremadura, Unidad Asociada UEX-CSIC, Instituto de Investigación de Desarrollo \\ Territorial Sostenible (INTERRA), 10003 - Cáceres, Spain \\ 2. Departamento de Cementos y Reciclado de Materiales, Instituto de Ciencias de la Construcción \\ Eduardo Torroja (IETCC-CSIC), 28033 - Madrid, Spain \\ Corresponding author: ingepisuerga@gmail.com / ${ }^{* *}$ cemedmart@yahoo.es
}

\begin{abstract}
This study explores the effect of replacing $10 \%$ and $20 \%$ of portland cement with BBA from three biomass-fired power plants on new design cement sorptivity, capillary absorption, electrical resistivity, drying shrinkage, expansion and heat of hydration. The findings show that although this addition induces an increase in water uptake due to its effect on the pore system, it does not compromise cement quality, which is international recommendation-compliant. As these new cements have the same or higher resistivity than the reference material, they are at least as corrosion-resistant as OPC. Binders bearing BBA exhibit less shrinkage and swelling than conventional cement and their peak heating, rate of heat release and total heat flow values are lower, particularly at the higher replacement ratio. The conclusion drawn is that the durability of the recycled product, which qualifies as a strength class 42.5 , type II/A cement, is unaffected by the partial replacement of clinker with BBA.
\end{abstract}

Keywords: transport in cement, shrinkage, expansion, heat of hydration, biomass bottom ash, recycled cements

\section{INTRODUCTION}

Cement is the binder most abundantly used in construction, with worldwide plant output in 2017 amounting to $4.65 \cdot 10^{9}$ tonnes [1]. Due to the high temperatures $\left(\sim 1450^{\circ} \mathrm{C}\right)$ required for its manufacture $(\sim 12 \%$ to $15 \%$ of industrial energy consumption [2]), $10 \%$ of worldwide anthropogenic $\mathrm{CO}_{2}$ emissions can be attributed to cement production [3].

Given those figures and against the backdrop of the pursuit of a circular economy, the cement industry and the scientific community have intensified their search for supplementary 
cementitious materials (SCMs) drawn from fired-clay, agri-food and ornamental stone industry waste. These endeavours aim to reduce natural resource consumption by lowering the clinker content in cement; contribute to $\mathrm{CO}_{2}$ emissions abatement by moderating the energy consumed in cement manufacture; and mitigate the environmental impact attributed to the construction industry $[4,5]$.

Particular attention has been devoted in recent years to research on SCMs based on agroindustry waste, for the world output of biomass comes to approximately $140 \cdot 10^{9}$ tonnes yearly [6]. More specifically, laboratory-scale experimentation has focused on burning biomass waste (primarily bagasse and rice husk and to a lesser extent bamboo ash [7-9]) at different temperatures, while biomass waste from power or heat and power plants has been studied much less profusely [10] [11, 12]. The few studies published on the subject have concentrated on the effect of adding biomass bottom ash (BBA) to cement on the mechanical strength of the resulting mortars. The findings reported vary with both the origin and composition of the waste and the replacement ratio used.

Those discrepancies are indicative of the breadth of the scientific-technical gap in the knowledge of the durability of materials bearing BBA. Understanding is scant, for instance, around the indirect indicators of durability such as sorptivity, capillarity and electrical resistivity [13]; micro- or macro-cracking induced by early age drying shrinkage or swelling and its adverse effect on service life [14]; and the steep thermal gradients generated by heat of hydration, with the concomitant cracks that may serve as channels for the ingress of aggressive external agents [15]. Such factors may compromise structural durability, particularly where large volumes of concrete are involved, such as in dams and dykes where the release of hydration heat is constrained [15].

Of cardinal importance, then, for furthering the valorisation of waste as a construction material is an understanding of both the economics and performance of SCM-bearing cement and the properties of the material that directly impact the durability of the resulting concrete. The economic significance of concrete member durability was quantified by Nath et al. [16], who estimated that approximately $\$ 18 \cdot 10^{9}$ to $\$ 21 \cdot 10^{9}$ are spent yearly to repair, rehabilitate, strengthen and protect concrete structures. 
This study consequently aims to contribute to an in-depth understanding of the effect of replacing $10 \%$ or $20 \%$ of portland cement with BBA on the mechanical strength and durability of new design cements. The variables studied include $28 \mathrm{~d}$ mortar mechanical performance and cement pore size distribution, sorptivity, capillarity, resistivity, drying shrinkage and swelling, along with the semi-adiabatic calorimetry determination of heat released during hydration.

\section{MATERIALS AND EXPERIMENTAL}

\subsection{Materials}

* Biomass bottom ash (BBA): biomass waste from three Spanish electric power plants was studied. Two of those plants used non-woody (primarily wheat, rye, oat and corn straw) and the third woody (eucalyptus, fruit and pine tree) waste to fire their boilers. The former two plants were labelled S1 and S2 and the third S3. The samples were collected randomly at three heights in the stockpiles and subsequently dried, ground and analysed for their chemical, physical and mineralogical characteristics, as reported in an earlier paper [17].

The X-ray fluorescence-determined chemical composition of all three BBAs revealed that they contained $65 \mathrm{wt} \%$ to $75 \mathrm{wt} \% \mathrm{CaO}+\mathrm{MgO}+\mathrm{SiO}_{2}, 13 \mathrm{wt} \%$ to $17 \mathrm{wt} \% \mathrm{~K}_{2} \mathrm{O}$ and $2.5 \mathrm{wt} \%$ to $5 \mathrm{wt} \%$ $\mathrm{Al}_{2} \mathrm{O}_{3}+\mathrm{Fe}_{2} \mathrm{O}_{3}$. According to the Vassilev diagram [18-20], those values are indicative of type $\mathrm{S}$, subtype medium acid (MA) biomass. All three also exhibited a reactive silica content of over $25 \%: 48.5 \%$ (S1), $44.7 \%(\mathrm{~S} 2)$ and $28.2 \%$ (S3) [17].

* Sand: the CEN-standard sand used to prepare the mortars had a particle size ranging from $2.0 \mathrm{~mm}$ to $0.08 \mathrm{~mm}$, as specified in EN 196-1 [21].

* Cement: the EN 197-1 [22]-compliant CEM I 42.5 R ordinary portland cement (OPC) used was furnished by Lafarge, a Spanish cement manufacturer sited in the province of Toledo.

\subsection{Blends}

The blended cements were prepared in a high-speed powder mixer to guarantee homogeneity. They were batched by weight, with OPC/BBA (S1, S2 and S3) ratios of 100/0 (OPC), 90/10 $(\mathrm{OPC}+10 \mathrm{BBA})$ and $80 / 20(\mathrm{OPC}+20 \mathrm{BBA})$, for a total of seven blends. The proportions were adopted on the grounds of the replacement ratios prescribed for type II/A (6 \%-20\%) and type IV/A (11\%-35\%) cements in European standard EN 197-1 [22].

The pore size distribution of the cements shown in Figure 1 was obtained by measuring $N_{2}$ absorption isotherms on a Micrometrics ASAP 2000 analyser. All the cements were observed to 
have pore diameters ranging from $0.7 \mathrm{~nm}$ to $200 \mathrm{~nm}$. The OPC had a small shoulder at $\sim 2.0 \mathrm{~nm}$ and cements OPC+10BBA and OPC+20BBA had two each, at $1.5 \mathrm{~nm}$ or $1.6 \mathrm{~nm}$ and $\sim 2.0 \mathrm{~nm}$. The shoulder at $1.5 \mathrm{~nm}$ was attributed to $\mathrm{S} 1$ and $\mathrm{S} 2$ in their respective blends, and the one at $1.6 \mathrm{~nm}$ to $\mathrm{S} 3$.

Figure 1. Pore size distribution of the cements studied

The effect of the new additions on the BET specific surface of the cements varied with the type of waste. On the one hand S2 induced a decline relative to OPC, with values of $1.30 \mathrm{~m}^{2} / \mathrm{g}$ in OPC+10S2 and $1.20 \mathrm{~m}^{2} / \mathrm{g}$ in OPC+20S2 compared to $1.37 \mathrm{~m}^{2} / \mathrm{g}$ in OPC and on the other S3 and $\mathrm{S} 1$ raised the value, to $1.92 \mathrm{~m}^{2} / \mathrm{g}$ in $\mathrm{OPC}+10 \mathrm{~S} 3,2.54 \mathrm{~m}^{2} / \mathrm{g}$ in $\mathrm{OPC}+20 \mathrm{~S} 3,1.41 \mathrm{~m}^{2} / \mathrm{g}$ in $\mathrm{OPC}+10 \mathrm{~S} 1$ and $1.50 \mathrm{~m}^{2} / \mathrm{g}$ in OPC+20S1. Those data were governed by the specific surface recorded for the raw waste, which in descending order was S3>S1>S2 [17].

\subsection{Standard methods and mortar manufacture}

Table 1 lists the physical, mechanical, durability and aesthetic parameters assessed in the new cements, as well as the methodology and specimen sizes used.

Table 1. Mechanical and durability parameters studied

The parameters listed in the above table were measured on standardised mortars with a sand:binder ratio of 3:1, as specified in standard EN 196-1 [21].

\subsection{Instrumental techniques}

The instrumental techniques used to characterise the microstructure of the new cements and assess heating and heat of hydration are described below.

The pore size distribution of the $28 \mathrm{~d}$ mortars was analysed with a Micromeritics Autopore IV 9500 mercury porosimeter featuring operating pressures of up to $33000 \mathrm{psi}(227.5 \mathrm{MPa})$ and a pore diameter measuring range of $0.006-175 \mu \mathrm{m}$. This trial was conducted to ASTM standard D 4404 [28].

Heat of hydration was calculated using the semi-adiabatic method (Langavant calorimeter) specified in European standard EN 196-9 [27]. In that method the heating recorded in the mortar studied is compared to that of an inert reference mortar (mixed 12 months prior) and the value found is entered into Equation 1 to determine heat of hydration $(Q)$ :

$Q=\frac{c}{m_{c}} \theta_{t}+\frac{1}{m_{c}} \int_{0}^{t} \alpha \cdot \theta_{t} \cdot d t$ 
where: where $Q$ is heat of hydration (amount of heat released by the sample in $\mathrm{J} \cdot \mathrm{g}^{-1}$ ); $m_{c}$ the mass $(\mathrm{g})$ of the mortar tested; $t(\mathrm{~h})$ hydration time; $C\left(\mathrm{~J} .{ }^{\circ} \mathrm{C}\right)$ the total heat capacity in the calorimeter and the mortar tested; $\alpha\left(\mathrm{J}^{-1}{ }^{-0} \mathrm{o} \mathrm{C}^{-1}\right)$ the global thermal transmission coefficient; and $\theta_{\mathrm{t}}\left({ }^{\circ} \mathrm{C}\right)$ the difference between the calorimeter readings for the test and reference materials at time $t$.

The tests were conducted on an IBERTEST IB32-101 Langavant calorimeter.

\section{RESULTS AND DISCUSSION}

\subsection{Mechanical strength}

According to the compressive strength data in Table 2 for the mortars studied, irrespective of the addition and replacement ratio, all exhibited $28 \mathrm{~d}$ strength $\geq 42.5 \mathrm{MPa}$. The strength loss relative to OPC prompted by the inclusion of BBA was lower than the replacement ratio, with a decline of $0.6 \%$ to $5.8 \%$ in OPC+10BBA and of $13.5 \%$ to $14.7 \%$ in OPC+20BBA. That behaviour could be attributed primarily to two factors: the pozzolanicity of the new additions [17] and the greater total porosity of the new mortars (see Table 2), an outcome also observed by Kumar [29]. Rosales et al. [30] recorded similar findings, with a 12\% decline in compressive strength in materials bearing $20 \%$ light material-free BBA (40\% caked olive mill waste and $60 \%$ woody biomass from poplar, olive and pine trees). Those authors also observed that at the aforementioned replacement ratio, strength tumbled by up to $60 \%$ relative to the reference cement if the BBA was not crushed or the light material was not removed. The present findings showed somewhat better values than observed by García and Coutinho [31] and Sklivaniti et al. [32], who recorded $28 \mathrm{~d}$ compressive strength declines very close to the replacement ratio ( $\sim 5$ to $10 \%)$ for woody waste from a Portuguese power plant and a much steeper loss (20\% to $32 \%$ ) for cements with $2 \%$ to $10 \%$ olive pruning waste.

Table 2. Mechanical performance and pore system properties in $28 \mathrm{~d}$ mortars Irrespective of whether the addition was $\mathrm{S} 1, \mathrm{~S} 2$ or S3, at a replacement ratio of $10 \%$ flexural strength was $2.5 \%$ to $6.3 \%$ higher than in OPC. Although strength declined at $20 \%$, loss was less intense than observed for compressive strength. The explanation for these observations lies in the faster rise, in materials bearing pozzolans (BBA in this case), of flexural than compressive strength, yielding cement-based materials more elastic than OPC [33, 34]. The decline observed here at a $20 \%$ replacement ratio was similar to the $10 \%$ dip relative to the 
control mortar reported by Rosales et al. [30] for mortars with $20 \%$ caked olive dreg BBA bearing no light materials.

\subsection{Total porosity and pore size distribution}

Table 2 also gives the total porosity and mean pore size values for the $28 \mathrm{~d}$ mortars. The mortars prepared with BBA-bearing cement exhibited a rise in total porosity relative to OPC, although percentage-wise it was lower than the replacement ratio, at $1.6 \%$ to $9.0 \%$ for OPC+10BBA and $5.3 \%$ to $9.4 \%$ for OPC+20BBA. The mean pore size dropped, for whilst the volume of macropores $(\Phi>0.05 \mu \mathrm{m})$ barely varied, the capillary fraction $(0.007<\Phi<0.05 \mu \mathrm{m})$ rose substantially to 1.2 to 1.8 times the volume found in OPC (Figure 2).

Figure 2. Pore size distribution in $28 \mathrm{~d}$ mortars

The decline in pore size was consistent with reports by other authors using ground bagasse ash [35], biomass bottom ash [36] or bagasse ash [37] as pozzolanic additions in new cements.

\subsection{Electrical conductivity}

The decline in electrical conductivity the mortars studied over time depicted in Figure 3 was attributable primarily to cement phase hydration and BBA pozzolanicity. The concomitant formation of a more compact and contorted pore system hindered the mobility of dissolved ionic species [38]. Three regions can be distinguished on the graph: the first, up to $3 \mathrm{~d}$, in which the OPC+BBA mortars exhibited higher conductivity than OPC, particularly in the $24 \mathrm{~h}$ materials; a second, up to $21 \mathrm{~d}$, in which OPC+10BBA and OPC conductivity values were similar, whilst OPC+20BBA conductivity was slightly higher than in the reference; and a third where $O P C+10 B B A<O P C \approx O P C+20 B B A$.

Figure 3. Electrical conductivity versus time

The pozzolanic effect of BBA was particularly visible in the third region, where resistivity (the inverse of conductivity) varied more in the additioned mortars than in the OPC, with increments ranging from $3.6 \Omega \cdot \mathrm{m} /$ day to $5.6 \Omega \cdot \mathrm{m} /$ day in OPC +10 BBA and $4.0 \Omega \cdot \mathrm{m} /$ day to $5.8 \Omega \cdot \mathrm{m} /$ day in OPC+20BBA, compared to $1.80 \Omega \cdot \mathrm{m} /$ day in OPC. That effect was consistent with observations by Caneda et al. [39], who reported more complex and slower microstructural development in mortars additioned with coal tailings than in the reference.

The resistivity recorded here for the OPC+10BBA mortars, irrespective of the type of addition, was $3.2 \%$ to $10.9 \%$ higher than observed in OPC. That value is in line with the $\sim 6 \%$ rise in 
electrical resistivity relative to OPC observed by García and Sousa-Coutinho [31] for mortars with $10 \%$ power plant woody biomass ash. In contrast, $28 \mathrm{~d}$ electrical resistivity in the OPC+20BBA mortars was equal to $(\mathrm{OPC}+20 \mathrm{~S} 3)$ or $<2 \%$ lower than $(\mathrm{OPC}+20 \mathrm{~S} 1$ and OPC+20S2) in OPC, for the pozzolanic reaction was insufficient to offset the effect of cement dilution.

The better $28 \mathrm{~d}$ performance may be associated with several factors: a decline in alkali and $\mathrm{OH}^{-}$ content in the pore system induced by the additions, which would hinder ion mobility in the pore solution [40]; the prevalence of the effect of pore aqueous phase ion composition in cementbased materials in the early stages of hydration and its decline after hardening [40, 41]; and the BBA-mediated modification of the pore system [39].

Figure 3 also revealed the possible correlation between conductivity and time defined in a study by Andrade et al. [42] as per Equation 2:

$\sigma=\sigma_{o} \cdot(t)^{-q}$

where: $\sigma$ is conductivity at a given age; $\sigma_{0}$ is conductivity at the first age determined; $t$ is time, and $q$ is the ageing factor that represents hydration progress. The fourth parameter, $q$, is essential to establishing the durability models proposed by Andrade and D'Andrea [43] and laid down in Spain's Structural Concrete Code, EHE-08 [44]. The $q$ values given in Table 3 were observed to be higher for the new OPC+BBA type II/A cements than for type I conventional cement, as observed by Andrade and D'Andrea [42] for cement types II/V and II/P.

Table 3. Ageing factor and resistivity values for new $28 \mathrm{~d}$ mortars

The inference drawn from the values for $28 \mathrm{~d}$ electrical resistivity was that the inclusion of BBA had no adverse effect on that durability indicator, for all the materials exhibited values lying within the $100 \Omega \cdot \mathrm{m}$ to $200 \Omega \cdot \mathrm{m}$ range defined in a number of proposed classifications as moderate reinforcement corrosion risk $(\mathrm{M})[45,46]$.

\subsection{Shrinkage}

The shrinkage values in Figure 4 for mortars dried for $40 \mathrm{~d}$ in air at $20^{\circ} \mathrm{C}$ and $60 \% \mathrm{RH}$ show that early age shrinkage was less intense in the S2 mortars and more intense in the S1 and S3 materials than in OPC. The shrinkage rate continued to grow from $2 \mathrm{~d}$ to $35 \mathrm{~d}$ and then to flatten, in which region the BBA-bearing mortars were observed to shrink less than the OPC 
specimens. The difference was wider at higher replacement ratios, with $1.3 \%$ to $6.5 \%$ less shrinkage relative to OPC at a ratio of $10 \%$ and $8.1 \%$ to $11.9 \%$ at $20 \%$ replacement.

Such lesser shrinkage in the additioned mortars would be due to the interaction among a number of factors over time. Lower heat of hydration would translate into less shrinkage, further to the relationship between these two properties observed by Hu et al. [47] and Zhan et al. [48]. Fineness affects shrinkage [48], with greater fineness $(O P C+20 S 3>O P C+10 S 3>O P C+20 S 1>$ $\mathrm{OPC}+10 \mathrm{~S} 1>\mathrm{OPC}>\mathrm{OPC}+10 \mathrm{~S} 2>\mathrm{OPC}+20 \% \mathrm{~S} 2)$ associated with more shrinkage, particularly at early ages. A third factor is the BBA-mediated pozzolanic reaction, observed by Chi [49] between bagasse ash and the portlandite resulting from cement hydration.

Figure 4. Drying shrinkage in mortars dried in air for $40 \mathrm{~d}$ at $20^{\circ} \mathrm{C}$ and $60 \% \mathrm{RH}$ The present findings were consistent with observations reported earlier by Chi [49], who found $\sim 10 \%$ more shrinkage in the reference than in mortars with $20 \%$ or greater bagasse ash as cement replacements. In contrast, other authors recorded greater shrinkage in mortars additioned with agro-industrial waste (palm oil fuel ash [50] and olive biomass bottom ash [30]), due primarily to the greater porosity of the additions and its effect on new mortar microstructure.

\subsection{Expansion}

The expansion observed in the mortars after immersion in water for $40 \mathrm{~d}$ at a temperature of $20^{\circ} \mathrm{C}$ graphed in Figure 5 shows that the volume of all the mortars tested rose due to the sorptivity of C-S-H gels, which tend to sponge when in contact with fluids [51, 52]. The mortars bearing these new additions expanded less than the OPC due to their lower C-S-H gel content, the result of cement dilution with the inclusion of BBA and the pozzolanicity of the latter, which increases with age, with $180 \mathrm{~d}$ pastes exhibiting amounts of gel similar to those found in OPC [53]. The smaller C-S-H gel content played a significant role in this process, prevailing over the effect of water absorption.

Figure 5. Expansion in mortars immersed in water at $20^{\circ} \mathrm{C}$

\subsection{Total absorption}

Table 4 gives the water absorption in the $28 \mathrm{~d}$ mortars, which was observed to rise relative to OPC with BBA replacement, by $1.0 \%$ to $6.7 \%$ for OPC+10BBA and $2.8 \%$ to $7.2 \%$ for OPC+20BBA. The data recorded were in keeping with the linear relationship between water absorption and total porosity, at a correlation coefficient of $\geq 0.90$ (Table 4), as reported earlier 
by other authors $[46,54]$. The water absorption values for the mortars studied were below the $10 \%$ ceiling recommended for high quality cement-based materials [12, 55].

Table 4. Water absorption

\subsection{Capillary absorption}

The capillary absorption curves plotted in Figure 6 proved to be similar for all three mortars studied, while also showing that the inclusion of BBA, irrespective of origin, induced a rise in water uptake due to the higher volume of capillary pores (Figure 2). These curves were characterised by three stages. The first or primary absorption stage ran from $5 \mathrm{~min}$ to $360 \mathrm{~min}$ $\left(0.29-2.45 \mathrm{~h}^{0.5}\right)$, during which capillary suction, the prevailing mechanism, determined rapid absorption. In secondary absorption, from $1 \mathrm{~d}$ to $7 \mathrm{~d}\left(4.90-13.11 \mathrm{~h}^{0.5}\right)$, suction slowed due to the filling of the larger pores [55] and the hydration and rehydration of paste components, modifying the microstructure with an impact on pore connectivity $[56,57]$. In the third stage (> $13.11 \mathrm{~h}^{0.5}$ ) the sample was saturated and maintained a constant weight, with diffusion governing water uptake in the air pores [58].

Figure 6. Capillary absorption curves in mortars

Table 5 gives the initial (Ip) and secondary (Is) sorptivity values using the fourth root of time, as recently proposed by Villagrán et al. [59] to obtain a higher correlation coefficient $\left(R^{2}>0.98\right)$ than delivered by the square root of time. According to those authors, C-S-H gel swelling modifies the pore size distribution in cement-based materials in contact with water, reducing hydraulic diffusion as a result of restricted material deformation. The data tabled show that during both initial and secondary sorptivity the inclusion of BBA hastened water penetration as a result of capillary suction, yielding sorptivity values $6.5 \%$ to $10.75 \%$ higher in OPC+10BBA mortars and $17.6 \%$ to $38.2 \%$ in OPC+20BBA mortars than in OPC. That rise in sorptivity was slightly below the values reported by Rosales et al. [30], who recorded increases in this parameter of around $48 \%$ when they additioned cement with $20 \%$ of olive tree- and other plant material-based BBA.

Table 5. Sorptivity and correlation coefficients calculated from the linear relationship between capillary absorption and the fourth root of time

The findings given in the table were the direct result of the effect of BBA on the pore size distribution of the new mortars (Figure 2 and Table 2), i.e., a higher volume of capillary pores 
$(\Phi<0.05 \mu \mathrm{m})$ and lower mean pore size. Translated into the graphs in Figure 7 , the data attest to the linear relationship between these two pore system parameters (capillary pore volume and mean pore size) and mortar sorptivity, a relationship observed earlier by Martys and Ferraris [60]. The same trend was recorded by other authors using woody bottom ash [31], fly ash [61], granite sludge [46] and granulated blast furnace slag [62] as partial cement replacements.

Figure 7. Correlation between pore system parameters and mortar sorptivity Alexander et al. [63], Ho et al. [64] and Jiménez and Montero [65] propose a classification for judging concrete durability from its sorptivity values. In that scheme, concretes with sorptivity of under $6 \mathrm{~mm} / \mathrm{h}^{0.5}$ are durable, although other authors [66] have proposed lowering the threshold to $3 \mathrm{~mm} / \mathrm{h}^{0.5}$ for reasons of safety. Browne [67], in turn, proposed another classification for concrete quality, requiring sorptivity of $0.1 \mathrm{mg} / \mathrm{mm}^{2} \cdot \mathrm{min}^{0.5}$ to $0.2 \mathrm{mg} / \mathrm{mm}^{2} \cdot \mathrm{min}^{0.5}$ to qualify as medium quality. Based on the aforementioned classifications, the new mortars can be said to deliver good performance in terms of capillary water uptake, with the inclusion of BBA proving to be non-detrimental in that respect.

\subsection{Heat of hydration}

The fluctuation in heat of hydration for all the mortars analysed is shown in the insert in Figure 8. The slope on the linear regression line for the upward arm plotted in the larger figure represents the heating rate. The heat curve can be divided into two stages: a first ending at peak heating which, depending on the mortar, ranged from $16 \mathrm{~h}$ to $21 \mathrm{~h}$ after the onset of hydration and a second, extending from that peak time after which heating progressively declined.

Figure 8. Mortar heating vs time from $3 \mathrm{~h}$ to $25 \mathrm{~h}$

Table 6 lists the terms of the linear regression equation (Equation 3 below) between time and heating, along with peak heating and the time it occurred.

$H=v_{\text {cal }} \times t-B$

where: $H$ is heating in ${ }^{\circ} \mathrm{C}$ at a given time $\mathrm{t} ; v_{c a l}$ is the heating rate in ${ }^{\circ} \mathrm{C} / \mathrm{h} ; t$ is hydration time between $3 \mathrm{~h}$ and $20 \mathrm{~h}$; and $B$ is a constant.

The table clearly shows the steady decline in peak heating with rising replacement ratios, with values $8.6 \%$ to $12.8 \%$ lower in mortar OPC+10BBA than in OPC and $13.8 \%$ to $17.7 \%$ lower in mortars OPC+20BBA. Similar behaviour has been reported in cements containing other 
pozzolanic materials such as paper mill sludge [68], fly ash [69], fired clay-based sanitary ware [15] construction and demolition waste [70] or milled ash [71] at varying replacement ratios.

Table 6. Heat of hydration in mortars versus time

The curves showing the time at which peak heating was reached in the additioned mortars were shifted to the right relative to the curve for OPC (Figure 8), denoting a delay induced by the additions. Peak heating time was approximately 1.23 times longer than OPC for the OPC+10BBA mortars and 1.28 times for the OPC+20BBA materials. Lesser and slower heating enhances durability, particularly when large volumes of bulk concrete are involved, for one of the factors with the heaviest impact on that property is the heat of hydration generated in the first $10 \mathrm{~h}$ to $20 \mathrm{~h}$, given the steep thermal gradients induced by the low thermal conductivity of these matrices.

The slope on the heating - hydration time ( $3 \mathrm{~h}$ to $20 \mathrm{~h}$ ) curve $\left(\mathrm{v}_{\text {cal }}\right)$ declined as the replacement ratio rose (Table 6), an indication that dilution prevailed over the pozzolanic reaction in this initial stage. The linear equations (Equation 1) relating heating versus time for all the mortars had $R^{2}$ values of $\geq 0.98$. Heating rate in the new mortars relative to the OPC value was 0.55 to 0.63 times lower for the OPC+10BBA and 0.51 to 0.57 times lower for the OPC+20BBA mortars. Asensio et al. [70] also observed lower heating rates in mortars with $10 \%$ and $30 \%$ construction and demolition waste than in pure OPC mortars, with rates ranging from 0.60 to 0.42 times less in the additioned than in the unadditioned materials.

Heat of hydration in the mortars analysed is plotted against time (up to $120 \mathrm{~h}=5 \mathrm{~d}$ ) in Figure 9 .

Figure 9. Total heat of hydration in mortars versus time

Heat of hydration rose rapidly in the first $24 \mathrm{~h}$, and then more slowly, peaking at $35 \mathrm{~h}$ and remaining essentially flat through the end of the test. As the replacement ratio rose, the heat released after $120 \mathrm{~h}$ was $3.7 \%$ to $6.3 \%$ lower in mortar OPC+10BBA and $10.1 \%$ to $11.8 \%$ lower in OPC+20BBA than in OPC. The decline observed was consistent with a trend reported by authors $[46,72,73]$ studying the early age effect of low pozzolanicity mineral additions (fly ash and granite sludge), as well as by Sánchez de Rojas et al. [74, 75] and Rodríguez et al. [68], analysing additions with higher pozzolanic activity such as spent FCC and paper sludge. That behaviour can be explained by the linear relationship between heat of hydration and the 
replacement ratio observed by Shanahan et al. [76], who proposed a linear model (Equation 4 below) to predict heat of hydration in cements additioned with fly ash and metakaolin.

$Q_{t}=A \cdot X_{B B A}+B$

where: $Q_{t}$ is heat of hydration at time $\mathrm{t}$, in $\mathrm{J} / \mathrm{g} ; A$ is the slope of the linear curve; $X_{B B A}$ is the biomass bottom ash content in wt\% and $B$ is a constant.

Table 7 gives the value of the terms in Equation 4 for $41 \mathrm{~h}$ and $120 \mathrm{~h}$ by type of addition.

Table 7. Regression equations and terms for the relationship between replacement ratio and heat of hydration released by mortars

Figure 9 also shows that further to EN 197-1 [22] specifications, all the new eco-efficient cements would be classified as ordinary cements, for their $41 \mathrm{~h}$ heat of hydration was $>270 \mathrm{~J} / \mathrm{g}$.

\section{CONCLUSIONS}

The conclusions that may be drawn from this study are set out below.

- New cements bearing $10 \%$ or $20 \%$ biomass bottom ash meet the strength requirements laid down in the standards in place for cement type II/A, strength class $42.5 \mathrm{~N}$ or $42.5 \mathrm{R}$.

- The inclusion of BBA reduces mean pore size relative to OPC, more intensely at the higher replacement ratio.

- At a replacement ratio of $10 \%$, BBA raises electrical resistivity by $3.1 \%$ to $10.9 \%$ relative to OPC, whilst at $20 \%$ the effect is nil. Irrespective of the replacement ratio, BBA raises the ageing factor, affording these new binders greater corrosion resistance than observed in OPC.

- The partial replacement of cement with BBA reduces drying shrinkage and expansion in the new materials, lowering the risk of early age cracking that could compromise their durability and shorten their service life.

- Water absorption is higher in the new cements than in OPC, by $1.0 \%$ to $6.7 \%$ at $10 \%$ replacement and $2.8 \%$ to $7.2 \%$ at $20 \%$ replacement. All the materials studied have lower than the $10 \%$ water absorption ceiling recommended for high quality mortars.

- Inclusion of BBA raises capillary suction relative to OPC by $10.7 \%$ at $10 \%$ replacement and $38.2 \%$ at a $20 \%$ ratio. The inclusion of this waste does not lower mortar quality, however, for all the materials analysed lie in the medium quality range defined in international recommendations. 
- Mortar heating rate, largely governed by waste content, is 0.51 times lower than the OPC value in mortar OPC+10BBA and 0.63 times lower in mortar OPC+20BBA. In other words, the higher the percentage of waste, the longer it takes to reach peak heating.

- Mortar peak heating values decline linearly with the percentage of BBA, by $8.6 \%$ to $12.8 \%$ in mortar OPC+10BBA and $13.8 \%$ to $17.7 \%$ in mortar OPC+20BBA.

- Heat of hydration is up to $6.3 \%$ lower in OPC+10BBA cement than in OPC and up to $11.8 \%$ lower in OPC+20BBA, narrowing the likelihood of early age cracking.

As adding BBA at less than or equal to $20 \%$ has no adverse effect on the durability parameters analysed, this waste can be used in the design of new binders equivalent to conventional type II/A cements. Such findings may spur the implementation of circular economy tenets in the cement industry.

\section{Conflict of interest}

None.

\section{Acknowledgements}

This study was funded by the Spanish Ministry of Science and Innovation under project BIA BIA2016-76643-C3-1-R, as well as by the Government of Extremadura and the European Regional Development Fund (ERDF) under grant GR 18122 awarded to the MATERIA research group.

\section{References}

[1] CEMBUREAU, Activity report 2017, Brussels, https://cembureau.eu/media/1716/activityreport-2017.pdf [accessed date:2019/01/30], 2019.

[2] A. Souto-Martinez, J. H. Arehart, W. V. Srubar, Cradle-to-gate CO2e emissions vs. in situ CO2 sequestration of structural concrete elements, Energy Build. 167 (2018) 301-311.

[3] R. Snellings, L. Horckmans, C. Van Bunderen, L. Vandewalle, Ö. Cizer, Flash-calcined dredging sediment blended cements: effect on cement hydration and properties, Mater. Struct. $50(2017) 241$.

[4] S. Allevi, M. Marchi, F. Scotti, S. Bertini, C. Cosentino, Hydration of calcium sulphoaluminate clinker with additions of different calcium sulphate sources, Mater. Struct. (2015) 1-14. 
[5] Y. H. Wu, R. Huang, C. J. Tsai, W. T. Lin, Recycling of Sustainable Co-Firing Fly Ashes as an Alkali Activator for GGBS in Blended Cements, Materials 8 (2015) 784-798.

[6] F. Martirena, J. Monzó, Vegetable ashes as Supplementary Cementitious Materials, Cem. Concr. Res. 114 (2018) 57 - 64.

[7] G. C. Cordeiro, K. E. Kurtis, Effect of mechanical processing on sugar cane bagasse ash pozzolanicity, Cem. Concr. Res. 97 (2017) 41-49.

[8] E. V. Morales, E. Villar-Cociña, M. Frías, S. F. Santos, H. Savastano Jr, Effects of calcining conditions on the microstructure of sugar cane waste ashes (SCWA): Influence in the pozzolanic activation, Cem. Concr. Compos. 31 (2009) 22-28.

[9] M. Frías, H. Savastano, E. Villar, M. I. Sánchez de Rojas, S. Santos, Characterization and properties of blended cement matrices containing activated bamboo leaf wastes, Cem. Concr. Compos. 34 (2012) 1019-1023.

[10] C. Fernández-Pereira, J. A. de la Casa, A. Gómez-Barea, F. Arroyo, C. Leiva, Y. Luna, Application of biomass gasification fly ash for brick manufacturing, Fuel 90 (2011) 220-232.

[11] R. Rajamma, R. J. Ball, L. s. A. C. Tarelho, G. C. Allen, J. o. A. Labrincha, V. M. Ferreira, Characterisation and use of biomass fly ash in cement-based materials, J. Hazard. Mater. 172 (2009) 1049-1060.

[12] C. B. Cheah, M. Ramli, The implementation of wood waste ash as a partial cement replacement material in the production of structural grade concrete and mortar: An overview, Resour. Conserv. Recycl. 55 (2011) 669-685.

[13] C. Medina, M. I. Sánchez de Rojas, C. Thomas, J. A. Polanco, M. Frías, Durability of recycled concrete made with recycled ceramic sanitary ware aggregate. Inter-indicator relationships, Constr. Build. Mater. 105 (2016) 480-486.

[14] C. Di Bella, M. Wyrzykowski, P. Lura, Evaluation of the ultimate drying shrinkage of cement-based mortars with poroelastic models, Mater. Struct. 50 (2017).

[15] C. Medina, I. F. Sáez del Bosque, E. Asensio, M. Frías, M. I. Sánchez de Rojas, New additions for eco-efficient cement design. Impact on calorimetric behaviour and comparison of test methods, Mater. Struct. 49 (2016) 4595-4607. 
[16] P. Nath, P. K. Sarker, W. K. Biswas, Effect of fly ash on the service life, carbon footprint and embodied energy of high strength concrete in the marine environment, Energy Build. 158 (2018) 1694-1702.

[17] J. M. Medina, I. F. Sáez del Bosque, M. Frías, M. I. Sánchez de Rojas, C. Medina, Characterisation and valorisation of biomass waste as a possible addition in eco-cement design, Mater. Struct. 50 (2017) 207.

[18] S. V. Vassilev, D. Baxter, L. K. Andersen, C. G. Vassileva, An overview of the composition and application of biomass ash.: Part 2. Potential utilisation, technological and ecological advantages and challenges, Fuel 105 (2013) 19-39.

[19] S. V. Vassilev, D. Baxter, L. K. Andersen, C. G. Vassileva, T. J. Morgan, An overview of the organic and inorganic phase composition of biomass, Fuel 94 (2012) 1-33.

[20] S. V. Vassilev, D. Baxter, L. K. Andersen, C. G. Vassileva, An overview of the chemical composition of biomass, Fuel 89 (2010) 913-933.

[21] European Committee for Standardization, EN 196-1. Methods of testing cement - Part 1: Determination of strength.

[22] European Committee for Standardization, EN 197-1. Cement. Composition, specifications and conformity criteria for common cements.

[23] Spanish Committee for Standardization, UNE 83988. Concrete durability. Test methods. Determination of the electrical resistivity. Part 2: Four point or Wenner method.

[24] Spanish Committee for Standardization, UNE 83980. Concrete durability. Test methods. Determination of the water absorption, density and accessible porosity for water in concrete.

[25] Spanish Committee for Standardization, UNE 83982. Concrete durability. Test methods. Determination of the capillar suction in hardened concrete. Fagerlund method.

[26] Spanish Committee for Standardization, UNE 80112. Test methods of cements. Physical analysis. Determination of contraction in air and expansion in water.

[27] European Committee for Standardization, EN 196-9. Methods of testing cement. Part 9: Heat hydration. Semi-adiabatic method.

[28] American Society for Testing and Materials, D 4404-84: Test method for determination of pore volume and pore volume distribution of soil and rock by mercury intrusion porosimetry. 
[29] P. Kumar Metha, P. J. M. Monteiro, Concrete: Microstructure, Properties and Materials, Third Edition ed., McGraw-Hill, United States of America, 2006, pp. 659.

[30] J. Rosales, M. Cabrera, M. G. Beltrán, M. López, F. Agrela, Effects of treatments on biomass bottom ash applied to the manufacture of cement mortars, J. Clean Prod. 154 (2017) 424-435.

[31] M. d. L. Garcia, J. Sousa-Coutinho, Strength and durability of cement with forest waste bottom ash, Constr. Build. Mater. 41 (2013) 897-910.

[32] V. Sklivaniti, P. E. Tsakiridis, N. S. Katsiotis, D. Velissariou, N. Pistofidis, D. Papageorgiou, M. Beazi, Valorisation of woody biomass bottom ash in Portland cement: A characterization and hydration study, Journal of Environmental Chemical Engineering 5 (2017) 205-213.

[33] F. Soria, Pozzolans and energy saving in building materials, Mater. Constr. 190 - 191 (1983) 69-84.

[34] M. I. Sánchez de Rojas, M. Frías, E. Sabador, E. Asensio, J. Rivera, C. Medina, Use of ceramic industry milling and glazing waste as an active addition in cement, J. Am. Ceram. Soc. 101 (2017) 2028-2037.

[35] S. Rukzon, P. Chindaprasirt, Strength, porosity, and chloride resistance of mortar using the combination of two kinds of pozzolanic materials, Int. J. Miner. Metall. Mater. 20 (2013) 808814.

[36] M. Cabrera, F. Agrela, J. Ayuso, A. P. Galvin, J. Rosales, Feasible use of biomass bottom ash in the manufacture of cement treated recycled materials, Mater. Struct. 49 (2016) 32273238.

[37] J. P. Moretti, A. Sales, V. A. Quarcioni, D. C. B. Silva, M. C. B. Oliveira, N. S. Pinto, L. W. S. L. Ramos, Pore size distribution of mortars produced with agroindustrial waste, J. Clean Prod. 187 (2018) 473-484.

[38] A. Joshaghani, M. A. Moeini, Evaluating the effects of sugar cane bagasse ash (SCBA) and nanosilica on the mechanical and durability properties of mortar, Constr. Build. Mater. 152 (2017) 818-831.

[39] L. Caneda-Martínez, M. Frías, C. Medina, M. I. S. de Rojas, N. Rebolledo, J. Sánchez, Evaluation of chloride transport in blended cement mortars containing coal mining waste, Constr. Build. Mater. 190 (2018) 200-210. 
[40] V. Baroghel-Bouny, K. Kinomura, M. Thiery, S. Moscardelli, Easy assessment of durability indicators for service life prediction or quality control of concretes with high volumes of supplementary cementitious materials, Cem. Concr. Compos. 33 (2011) 832-847.

[41] X. Wei, Z. Li, Early Hydration Process of Portland Cement Paste by Electrical Measurement, J. Mater. Civ. Eng. 18 (2006) 99-105.

[42] C. Andrade, R. d'Andréa, in: Pro061. International Conference on Microstructure Related Durability of Cementitious Composites, K. v. B. W. Sun, C. Miao, G. Ye and H. Chen, (Ed.) RILEM Publications: Delft, The Netherlands, 2008; pp 1483-1490.

[43] C. Andrade, R. D’Andrea, La resistividad eléctrica como parámetro de control del hormigón y su durabilidad, ALCONPAT, Mérida (México), 2011, pp. 93-101.

[44] Comisión Permanente del Hormigón, Instrucción Hormigón Estructural. EHE-08, Primera Edición ed., Ministerio de Fomento. Centro de Publicaciones, Madrid, 2008, pp. 704.

[45] C. Andrade, J. Fullea, C. Alonso, in: Measurement and Interpretation of the on-Site Corrosion Rate, C. Andrade, C. Alonso, J. Fullea, (Eds.) 2000; Vol. 18, pp 157-165.

[46] G. Medina, I. F. Sáez del Bosque, M. Frías, M. I. Sánchez de Rojas, C. Medina, Durability of new recycled granite quarry dust-bearing cements, Constr. Build. Mater. 187 (2018) 414-425. [47] X. Hu, C. J. Shi, Z. G. Shi, B. H. Tong, D. H. Wang, Early age shrinkage and heat of hydration of cement-fly ash-slag ternary blends, Constr. Build. Mater. 153 (2017) 857-865.

[48] W. Zhang, Y. Hama, S. H. Na, Drying shrinkage and microstructure characteristics of mortar incorporating ground granulated blast furnace slag and shrinkage reducing admixture, Constr. Build. Mater. 93 (2015) 267-277.

[49] M.-C. Chi, Effects of sugar cane bagasse ash as a cement replacement on properties of mortars, Sci. Eng. Compos. Mater. 19 (2012) 279-285.

[50] R. N. Gonzalez-Kunz, P. Pineda, A. Bras, L. Morillas, SPlant biomass ashes in cementbased building materials. Feasibility as eco-efficient structural mortars and grouts, Sust. Cities Soc. 31 (2017) 151-172.

[51] M. Lenart, Assessment of mortar shrinkage in aspect of organic and inorganic modifiers use, 7th Scientific-Technical Conference on Material Problems in Civil Engineering (Matbud'2015) 108 (2015) 309-315. 
[52] M. Fernández Cánovas, Hormigón, Octava Edición ed., Colegio de Ingenieros de Caminos, Canales y Puertos, Madrid, 2007, pp. 666.

[53] I. F. Sáez del Bosque, J. M. Medina, M. Frías, M. I. Sánchez de Rojas, C. Medina, Use of biomass-fired power plant bottom ash as an addition in new blended cements: effect on the structure of the C-S-H gel formed during hydration, Constr. Build. Mater. [Under Review].

[54] C. Medina, M. I. Sánchez de Rojas, M. Frías, Properties of recycled ceramic aggregate concretes: Water resistance, Cem. Concr. Compos. 40 (2013) 21-29.

[55] S. Gupta, H. W. Kua, Effect of water entrainment by pre-soaked biochar particles on strength and permeability of cement mortar, Constr. Build. Mater. 159 (2018) 107-125.

[56] C. Hall, W. D. Hoff, S. C. Taylor, M. A. Wilson, B. G. Yoon, H. W. Reinhardt, M. Sosoro, P. Meredith, A. M. Donald, Water anomaly in capillary liquid absorption by cement-based materials, J. Mater. Sci. Lett. 14 (1995) 1178-1181.

[57] L. Hanzic, L. Kosec, I. Anzel, Capillary absorption in concrete and the Lucas-Washbum equation, Cem. Concr. Compos. 32 (2010) 84-91.

[58] G. Fagerlund, On the capillarity of concrete, 1982, pp. 20.

[59] Y. A. Villagrán Zaccardi, N. M. Alderete, N. De Belie, Improved model for capillary absorption in cementitious materials: Progress over the fourth root of time, Cem. Concr. Res. 100 (2017) 153-165.

[60] N. S. Martys, C. F. Ferraris, Capillary transport in mortars and concrete, Cem. Concr. Res. 27 (1997) 747-760.

[61] A. Benli, M. Karatas, Y. Bakir, An experimental study of different curing regimes on the mechanical properties and sorptivity of self-compacting mortars with fly ash and silica fume, Constr. Build. Mater. 144 (2017) 552-562.

[62] J. Marcos, J. Sánchez, M. A. Climent, in: Advances in Modeling Concrete Service Life. Proceeding of 4th International RILEM PhD Workshop held in Madrid, J. G. C. Andrade, (Ed.) New York, 2010; pp 21-31.

[63] F. T. Olorunsogo, N. Padayachee, Performance of recycled aggregate concrete monitored by durability indexes, Cem. Concr. Res. 32 (2002) 179-185.

[64] D. W. S. Ho, I. Hinczak, J. J. Conroy, R. K. Lewis, Influence of slag cement on the water sorptivity of concrete, Madrid, Spain, 1986, pp. 1463-1473. 
[65] L. F. Jiménez, E. I. Moreno, Durability indicators in high absorption recycled aggregate concrete, Adv. Mater. Sci. Eng. (2015) 8.

[66] G. Menendez, V. L. Bonavetti, E. F. Irassar, Ternary blend cement concrete. Part II: Transport mechanisms, Mater. Constr. 57 (2007) 31-43.

[67] R. Browne, Field investigations: site \& laboratory tests: maintenance, repair and rehabilitation of concrete structures, Lisbon: CEEC, 1991.

[68] O. Rodriguez, M. Frias, M. I. Sanchez de Rojas, Influence of the calcined paper sludge on the development of hydration heat in blended cement mortars, J. Therm. Anal. 92 (2008) 865871.

[69] M. Frias, M. I. S. de Rojas, J. Cabrera, The effect that the pozzolanic reaction of metakaolin has on the heat evolution in metakaolin-cement mortars, Cem. Concr. Res. 30 (2000) 209-216.

[70] E. Asensio, C. Medina, M. Frías, M. I. Sánchez de Rojas, Use of clay-based construction and demolition waste as additions in the design of new low and very low heat of hydration cements, Mater. Struct. 51 (2018) 101.

[71] J. Rissanen, K. Ohenoja, P. Kinnunen, M. Illikainen, Partial Replacement of PortlandComposite Cement by Fluidized Bed Combustion Fly Ash, J. Mater. Civ. Eng. 29 (2017).

[72] M. Frías, M. I. Sánchez de Rojas, J. Cabrera, The effect that the pozzolanic reaction of metakaolin has on the heat evolution in metakaolin-cement mortars, Cem. Concr. Res. 30 (2000) 209-216.

[73] D. G. Snelson, S. Wild, M. O'Farrell, Heat of hydration of Portland Cement-Metakaolin-Fly ash (PC-MK-PFA) blends, Cem. Concr. Res. 38 (2008) 832-840.

[74] M. G. de Lomas, M. I. Sánchez de Rojas, M. Frias, Pozzolanic reaction of a spent fluid catalytic cracking catalyst in FCC-cement mortars, J. Therm. Anal. 90 (2007) 443-447.

[75] M. I. Sánchez de Rojas, M. Frías, The pozzolanic activity of different materials, its influence on the hydration heat in mortars, Cem. Concr. Res. 26 (1996) 203-213.

[76] N. Shanahan, V. Tran, A. Zayed, Heat of hydration prediction for blended cements, J. Therm. Anal. 128 (2017) 1279-1291. 
Table 1. Mechanical and durability parameters studied

\begin{tabular}{|c|c|c|c|}
\hline Property & Standard & $\begin{array}{l}\text { Specimen size } \\
(\mathrm{cm})\end{array}$ & $\begin{array}{c}\text { Water/ } \\
\text { cement ratio }\end{array}$ \\
\hline $\begin{array}{l}\text { Compressive and flexural } \\
\text { strength }\end{array}$ & EN 196-1 [21] & \multirow{4}{*}{$4 \times 4 \times 16$} & \multirow{4}{*}{0.50} \\
\hline Electrical resistivity & UNE 83988 [23] & & \\
\hline Sorptivity & UNE 83980 [24] & & \\
\hline Capillary absorption & UNE 83982 [25] & & \\
\hline Drying shrinkage & \multirow{2}{*}{ UNE 80112 [26] } & \multirow{2}{*}{$2.5 \times 2.5 \times 28.5$} & \multirow{2}{*}{0.47} \\
\hline Water-induced swelling & & & \\
\hline Heat of hydration & EN 196-9 [27] & - & 0.40 \\
\hline
\end{tabular}

Table 2. Mechanical performance and pore system properties in $28 \mathrm{~d}$ mortars

\begin{tabular}{|l|c|c|c|c|}
\hline \multirow{2}{*}{ Mortar } & \multicolumn{2}{|c|}{ Mechanical strength (MPa) } & \multicolumn{2}{c|}{ Pore system } \\
\cline { 2 - 5 } & Compressive & Flexural & $\begin{array}{c}\text { Total porosity } \\
(\% \text { vol.) }\end{array}$ & $\begin{array}{c}\text { Mean size [4V/A] } \\
(\boldsymbol{\mu m})\end{array}$ \\
\hline OPC & $68.22 \pm 1.73$ & $9.01 \pm 0.43$ & 11.59 & 0.0863 \\
\hline \multirow{2}{*}{ OPC+10S1 } & $\begin{array}{c}65.35 \pm 2.10 \\
(-4.21)\end{array}$ & $\begin{array}{c}9.24 \pm 0.43 \\
(+2.55)\end{array}$ & $\begin{array}{c}12.37 \\
(+6.73)\end{array}$ & $\begin{array}{c}0.0838 \\
(-2.90)\end{array}$ \\
\hline \multirow{2}{*}{ OPC+20S1 } & $\begin{array}{c}58.35 \pm 1.51 \\
(-14.47)\end{array}$ & $\begin{array}{c}8.74 \pm 0.09 \\
(-3.00)\end{array}$ & $\begin{array}{c}12.52 \\
(+8.02)\end{array}$ & 0.0779 \\
& $64.26 \pm 0.75$ & $9.38 \pm 0.46$ & 12.63 & $(-9.73)$ \\
\hline \multirow{2}{*}{ OPC+10S2 } & $(-5.80)$ & $(+4.11)$ & $(+8.97)$ & 0.0859 \\
& $59.01 \pm 0.37$ & $8.47 \pm 0.34$ & 12.68 & $(-0.46)$ \\
\hline \multirow{2}{*}{ OPC+20S2 } & $(-13.50)$ & $(-5.99)$ & $(+9.40)$ & 0.0695 \\
& $67.84 \pm 1.43$ & $9.58 \pm 0.41$ & 11.78 & $(-19.47)$ \\
\hline \multirow{2}{*}{ OPC+10S3 } & $(-0.56)$ & $(+6.33)$ & $(+1.64)$ & 0.0762 \\
& $58.17 \pm 0.94$ & $7.96 \pm 0.26$ & 12.20 & $(-11.70)$ \\
\hline \multirow{2}{*}{ OPC+20S3 } & $(-14.73)$ & $(-11.65)$ & $(+5.26)$ & 0.0704 \\
& \multicolumn{3}{|c|}{ Note. - In brackets: Relative strength respect to OPC expressed as percentage } \\
\hline
\end{tabular}


Table 3. Ageing factor and resistivity values for new $28 \mathrm{~d}$ mortars

\begin{tabular}{|l|c|c|c|c|}
\hline \multicolumn{1}{|c|}{ Mortar } & $\begin{array}{c}\text { Conductivity }\left(\sigma_{\mathbf{o}}\right) \\
{\left[\mathbf{( \Omega \cdot \mathbf { m } ^ { - 1 } ]}\right.}\end{array}$ & $\begin{array}{c}\text { Ageing } \\
\text { factor } \mathbf{( q )}\end{array}$ & $\mathbf{R}^{\mathbf{2}}$ & $\begin{array}{c}\text { Resistivity } \\
(\mathbf{\Omega} \cdot \mathbf{m})\end{array}$ \\
\hline OPC & 0.0213 & 0.315 & 0.953 & 142.00 \\
\hline OPC+10S1 & 0.0248 & 0.360 & 0.9554 & 154.00 \\
\hline OPC+20S1 & 0.0299 & 0.375 & 0.960 & 139.25 \\
\hline OPC+10S2 & 0.0223 & 0.322 & 0.952 & 146.00 \\
\hline OPC+20S2 & 0.0251 & 0.334 & 0.959 & 140.00 \\
\hline OPC+10S3 & 0.0251 & 0.370 & 0.958 & 157.00 \\
\hline OPC+20S3 & 0.0284 & 0.384 & 0.951 & 142.17 \\
\hline
\end{tabular}

Table 4. Water absorption

\begin{tabular}{|c|c|c|c|}
\hline Mortar & $\begin{array}{c}\text { Water absorption } \\
\text { (wt\%) }\end{array}$ & $\begin{array}{c}\text { Variation relative to } \\
\text { OPC }\end{array}$ & $\begin{array}{l}\text { Linear regression equation } \\
\text { for water absorption vs total } \\
\text { porosity }\end{array}$ \\
\hline OPC & 5.66 & & \multirow{7}{*}{$\begin{array}{c}W A=0.35 \times P_{t}+1.65 \\
R^{2}=0.91\end{array}$} \\
\hline OPC+10S1 & 5.85 & +3.25 & \\
\hline OPC+20S1 & 5.91 & +4.33 & \\
\hline OPC+10S2 & 6.04 & +6.70 & \\
\hline OPC+20S2 & 6.07 & +7.24 & \\
\hline $\mathrm{OPC}+10 \mathrm{S3}$ & 5.72 & +1.02 & \\
\hline OPC+20S3 & 5.82 & +2.80 & \\
\hline \multicolumn{4}{|c|}{ Note. - WA: Water absorption (wt\%); Pt: total porosity (vol. \%) } \\
\hline
\end{tabular}


Table 5. Sorptivity and correlation coefficients calculated from the linear relationship between capillary absorption and the fourth root of time

\begin{tabular}{|l|c|c|c|c|}
\hline \multirow{2}{*}{ Mortar } & \multicolumn{3}{|c|}{ Sorptivity } \\
\cline { 2 - 5 } & $\begin{array}{c}\text { Initial absorption } \\
\left(\mathbf{m m} / \mathbf{s}^{0.25}\right)\end{array}$ & $\begin{array}{c}\text { Secondary } \\
\text { absorption }\left(\mathbf{m m} / \mathbf{s}^{0.25}\right)\end{array}$ & $\begin{array}{c}\mathbf{S}^{*} \\
\left(\mathbf{m g} / \mathbf{m m}^{\mathbf{2}^{*}} \mathbf{m i n}^{\mathbf{0 . 5}}\right)\end{array}$ & $\begin{array}{c}\mathbf{S}^{*} \\
\left(\mathbf{m m} / \mathbf{h}^{0.5}\right)\end{array}$ \\
\hline OPC & $\begin{array}{c}0.212 \\
\left(R^{2}=0.999\right)\end{array}$ & $\begin{array}{c}0.066 \\
\left(R^{2}=0.990\right)\end{array}$ & 0.107 & 0.83 \\
\hline OPC+10S1 & $\begin{array}{c}0.228 \\
\left(R^{2}=0.994\right)\end{array}$ & $\begin{array}{c}0.0974 \\
\left(R^{2}=0.990\right)\end{array}$ & 0.114 & 0.89 \\
\hline OPC+20S1 & $\begin{array}{c}0.251 \\
\left(R^{2}=0.995\right)\end{array}$ & $\begin{array}{c}0.135 \\
\left(R^{2}=0.991\right)\end{array}$ & 0.126 & 0.98 \\
\hline OPC+10S2 & $\begin{array}{c}0.223 \\
\left(R^{2}=0.999\right)\end{array}$ & $\begin{array}{c}0.117 \\
\left(R^{2}=0.990\right)\end{array}$ & 0.116 & 0.87 \\
\hline OPC+20S2 & $\begin{array}{c}0.284 \\
\left(R^{2}=0.993\right)\end{array}$ & $\begin{array}{c}0.119 \\
\left(R^{2}=0.987\right)\end{array}$ & 0.143 & 0.92 \\
\hline OPC+10S3 & $\begin{array}{c}0.237 \\
\left(R^{2}=0.993\right)\end{array}$ & $\begin{array}{c}0.092 \\
\left(R^{2}=0.987\right)\end{array}$ & 0.119 & 1.15 \\
\hline OPC+20S3 & $\left(R^{2}=0.996\right)$ & $\begin{array}{c}0.112 \\
\left(R^{2}=0.991\right)\end{array}$ & 0.148 & 0.11 \\
\hline
\end{tabular}

Note. - *'S: sorptivity calculated as per ASTM C1585 for time $0.20 h^{0.5}$ to $2.45 h^{0.5}$; $R^{2}>0.98$

Table 6. Heat of hydration in mortars versus time

\begin{tabular}{|l|c|c|c|c|c|}
\hline \multirow{2}{*}{ Mortar } & \multirow{2}{*}{ Time (h) } & \multirow{2}{*}{$\left.\mathbf{H}_{\max } \mathbf{(}^{\circ} \mathbf{C}\right)$} & \multicolumn{3}{c|}{ Terms of Equation 3 } \\
\cline { 4 - 6 } & & & $\mathbf{V}_{\text {cal }}$ & $\mathbf{B}$ & $\mathbf{R}^{\mathbf{2}}$ \\
\hline OPC & 16.05 & 32.7 & 3.49 & 9.18 & 0.982 \\
\hline OPC+10S1 & 19.17 & 29.9 & 2.21 & 5.74 & 0.983 \\
\hline OPC+20S1 & 20.01 & 28.2 & 1.98 & 3.99 & 0.986 \\
\hline OPC+10S2 & 19.90 & 28.5 & 2.04 & 6.54 & 0.984 \\
\hline OPC+20S2 & 20.15 & 26.9 & 1.85 & 4.71 & 0.983 \\
\hline OPC+10S3 & 19.82 & 29.6 & 1.92 & 5.36 & 0.983 \\
\hline OPC+20S3 & 20.90 & 27.1 & 1.80 & 5.14 & 0.981 \\
\hline
\end{tabular}

Note. $\boldsymbol{H}_{\max }$ : peak heating; $\boldsymbol{v}_{\text {cal }}$ : heating rate $\left({ }^{\circ} \mathrm{C} / \mathrm{h}\right) ; \boldsymbol{t}$ : time $(\mathrm{t}) ; \boldsymbol{B}$ : constant in Equation 3 $\left({ }^{\circ} \mathrm{C}\right) ; \boldsymbol{R}^{2}$ : correlation coefficient 
Table 7. Regression equations and terms for the relationship between replacement ratio and heat of hydration released by mortars

\begin{tabular}{|c|c|c|c|c|}
\hline \multirow{2}{*}{ Correlation } & $\begin{array}{c}\text { Hydration time } \\
(\mathbf{h})\end{array}$ & \multicolumn{3}{|c|}{ Terms of Equation 4 } \\
\cline { 2 - 5 } & 41 & $\mathbf{A}$ & $\mathbf{B}$ & $\mathbf{R}^{\mathbf{2}}$ \\
\hline \multirow{2}{*}{ OPC vs OPC+XS1 } & 120 & -1.50 & 313.85 & 0.996 \\
\cline { 2 - 5 } & 41 & -2.00 & 312.53 & 0.975 \\
\hline \multirow{2}{*}{ OPC vs OPC+XS2 } & 120 & -1.92 & 320.57 & 0.998 \\
\cline { 2 - 5 } & 41 & -1.68 & 317.33 & 0.956 \\
\hline \multirow{2}{*}{ OPC vs OPC+XS3 } & 120 & -1.61 & 320.57 & 0.961 \\
\cline { 2 - 5 } & & & & \\
\hline
\end{tabular}




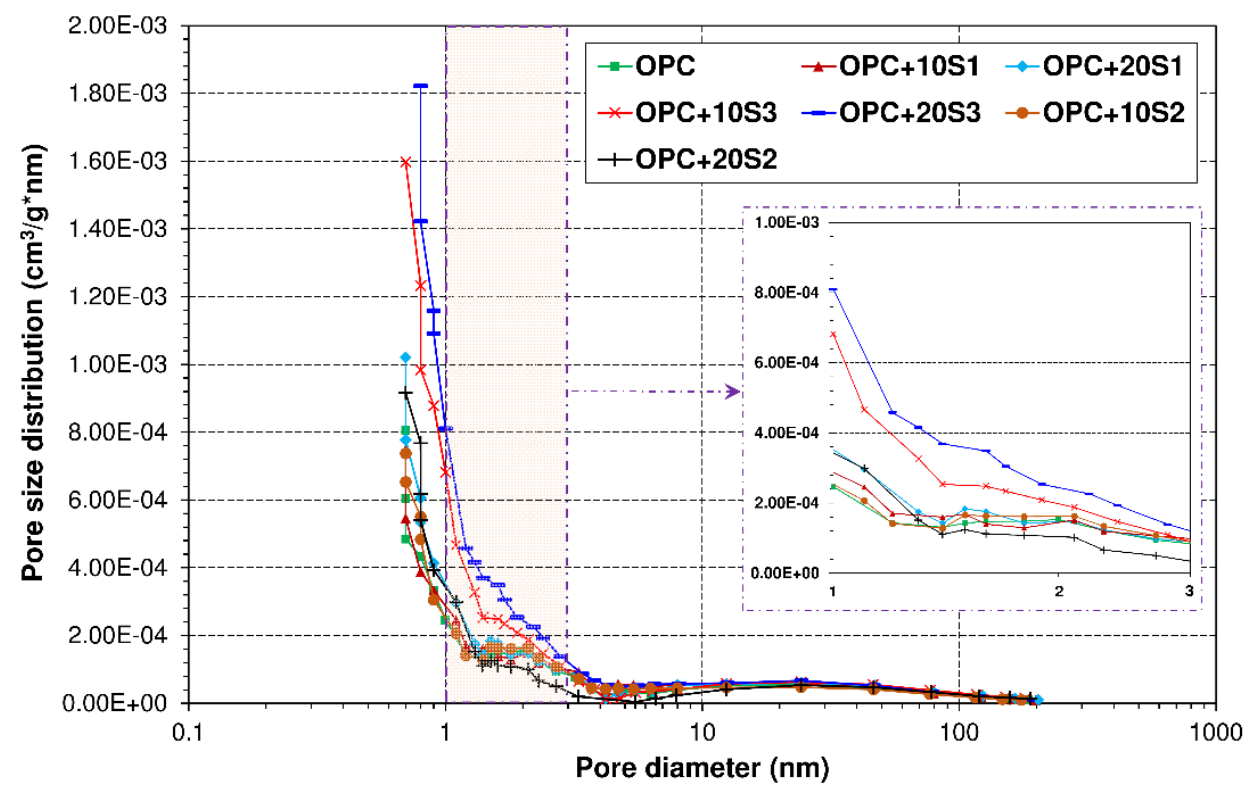

Figure 1. Pore size distribution of the cements studied

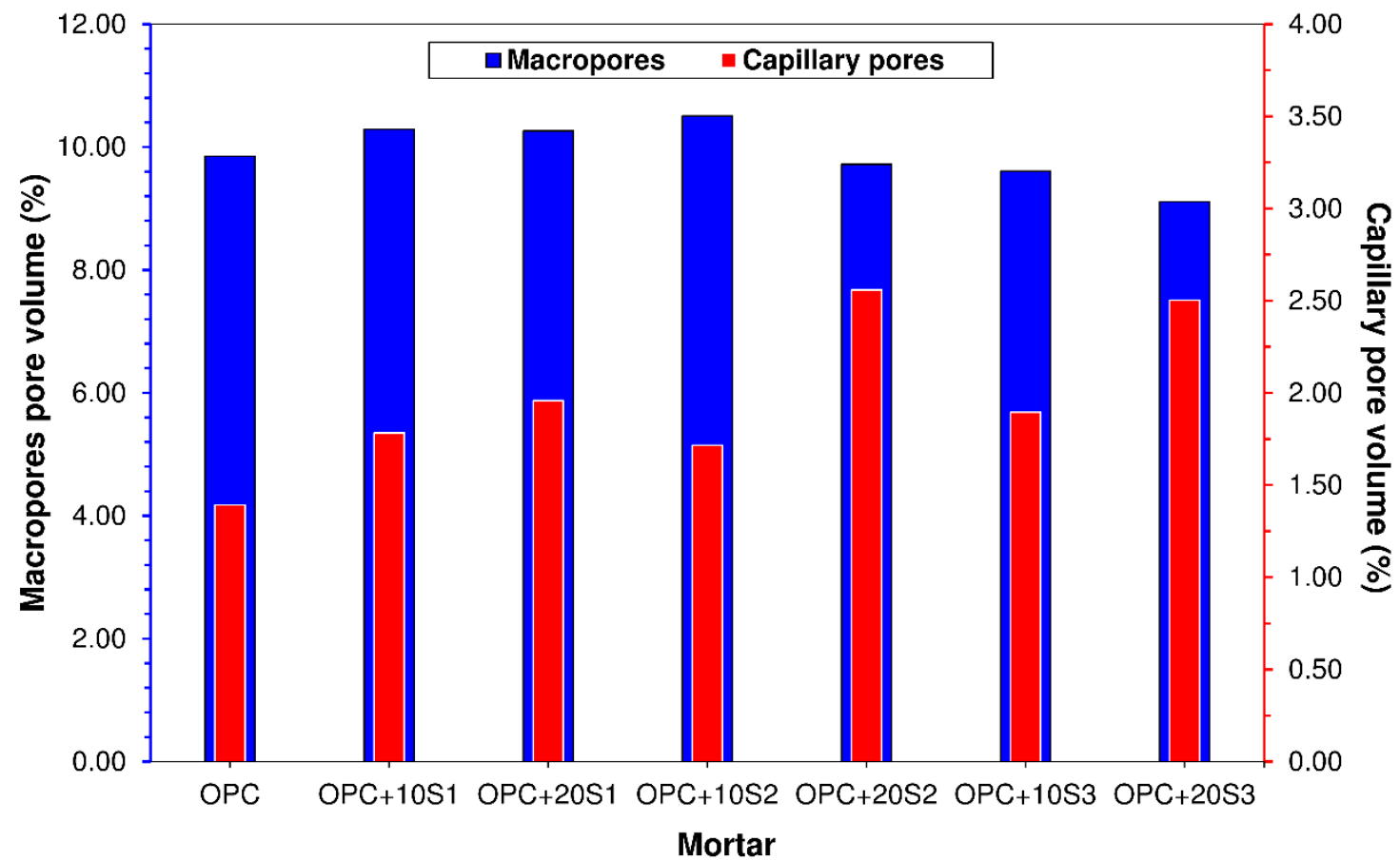

Figure 2. Pore size distribution in $\mathbf{2 8} \mathrm{d}$ mortars 


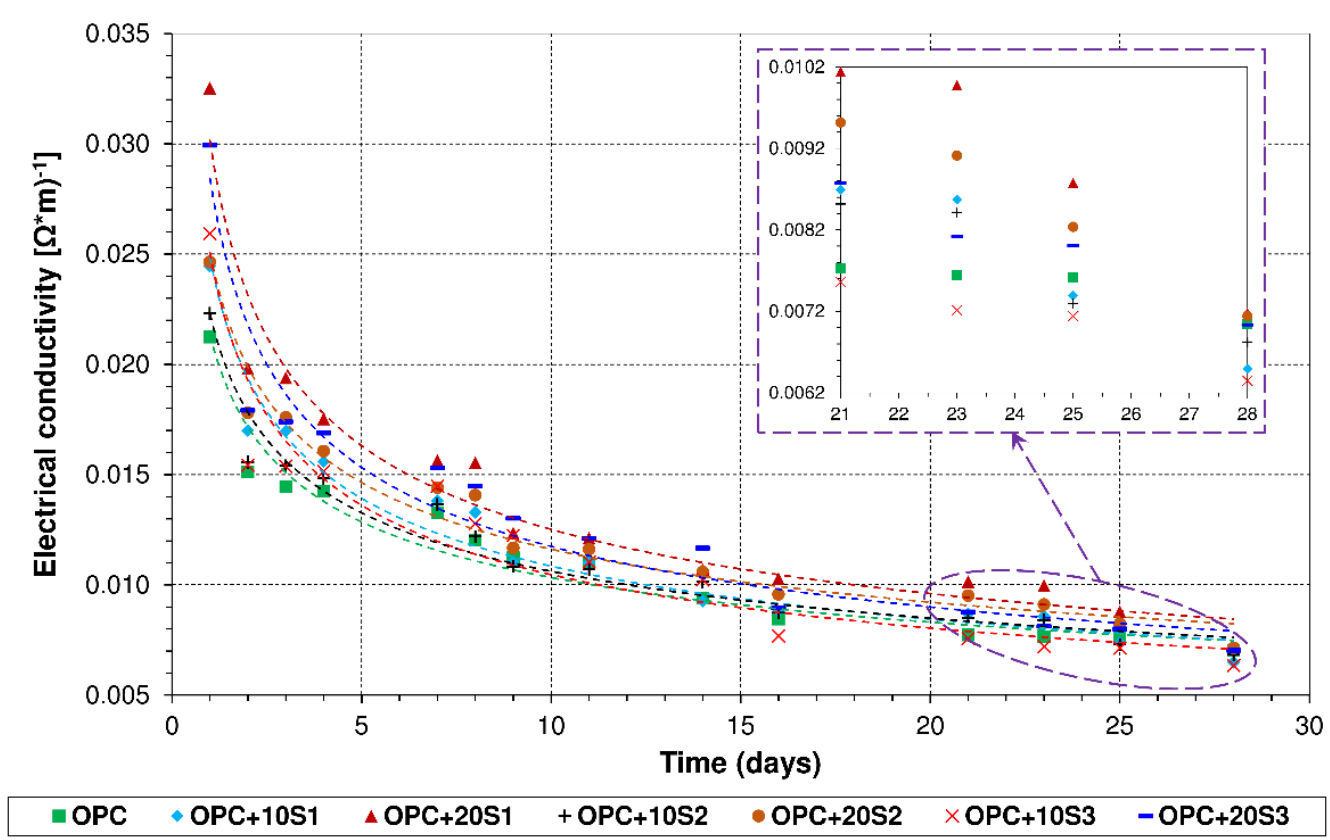

Figure 3. Electrical conductivity versus time

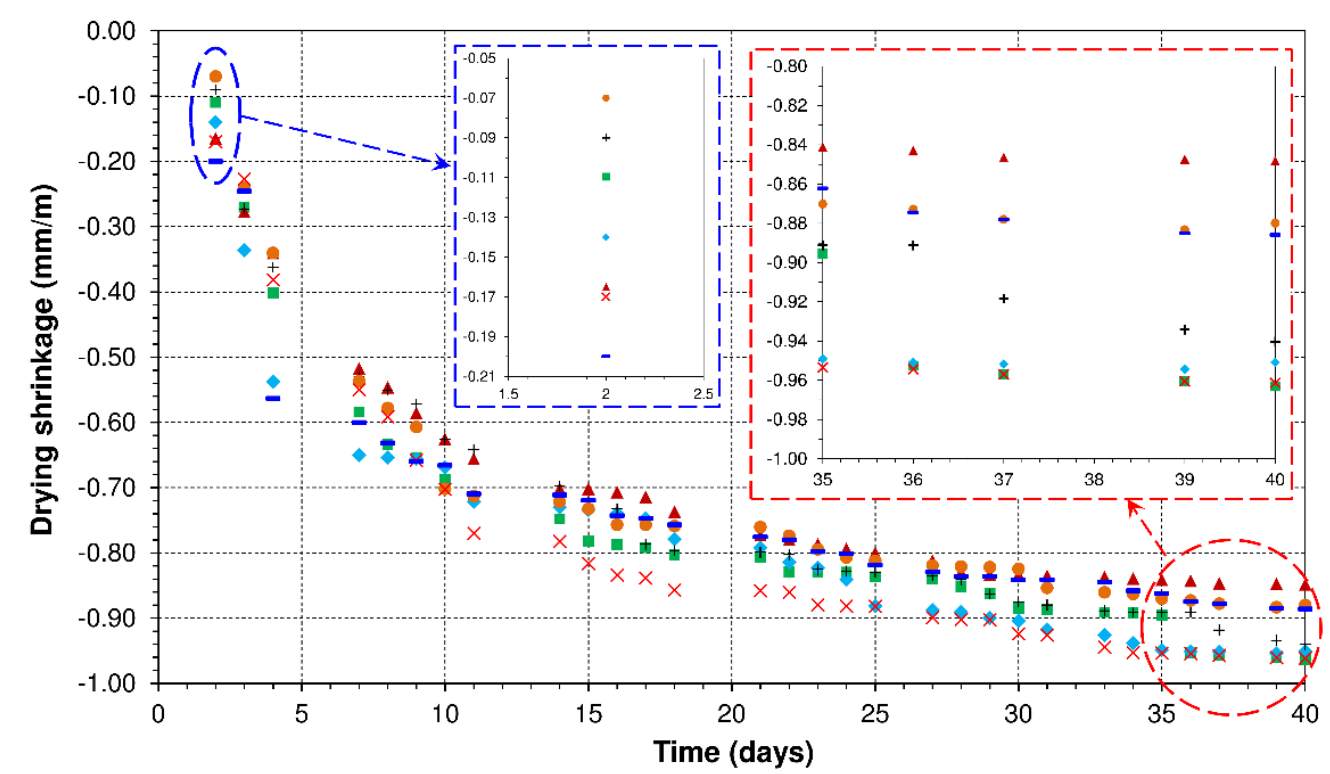

$=\mathrm{OPC}-\mathrm{OPC}+10 \mathrm{~S} 1 \triangle \mathrm{OPC}+20 \mathrm{~S} 1+\mathrm{OPC}+10 \mathrm{~S} 2 \cdot \mathrm{OPC}+20 \mathrm{~S} 2 \times \mathrm{OPC}+10 \mathrm{~S} 3-\mathrm{OPC}+20 \mathrm{~S} 3$

Figure 4. Drying shrinkage in mortars dried in air for $40 \mathrm{~d}$ at $20^{\circ} \mathrm{C}$ and $60 \% \mathrm{RH}$ 


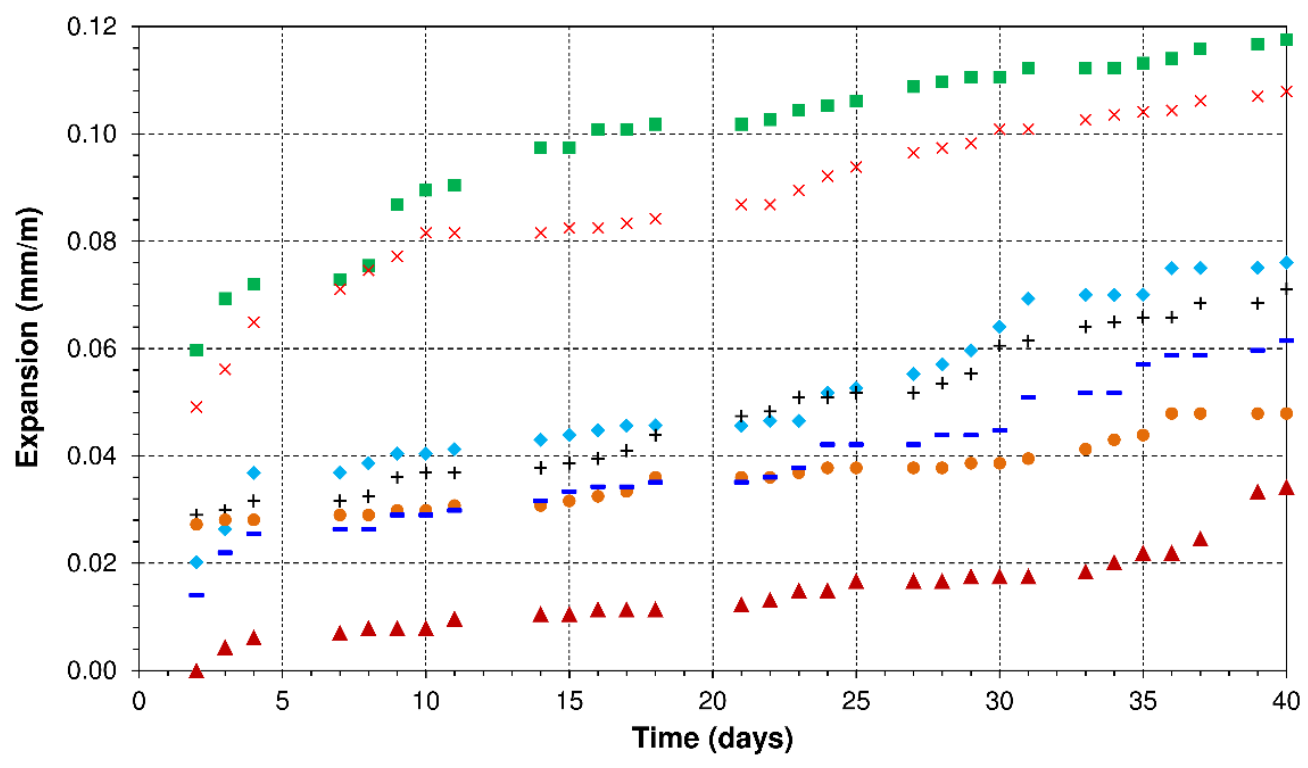

$\because \mathrm{OPC} \bullet \mathrm{OPC}+10 \mathrm{~S} 1 \triangle \mathrm{OPC}+20 \mathrm{~S} 1+\mathrm{OPC}+10 \mathrm{~S} 2 \cdot \mathrm{OPC}+20 \mathrm{~S} 2 \times \mathrm{OPC}+10 \mathrm{~S} 3-\mathrm{OPC}+20 \mathrm{~S} 3$

Figure 5. Expansion in mortars immersed in water at $20^{\circ} \mathrm{C}$

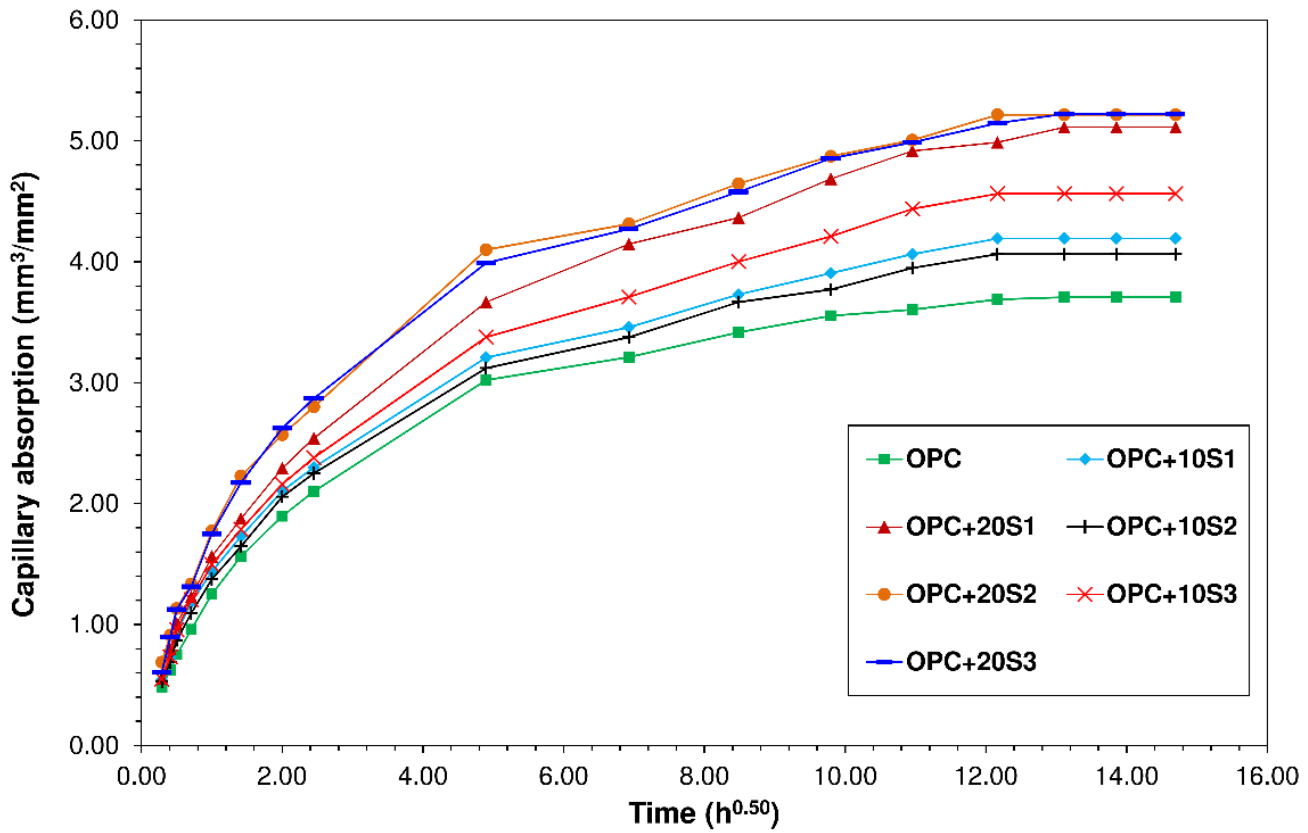

Figure 6. Capillary absorption curves in mortars 

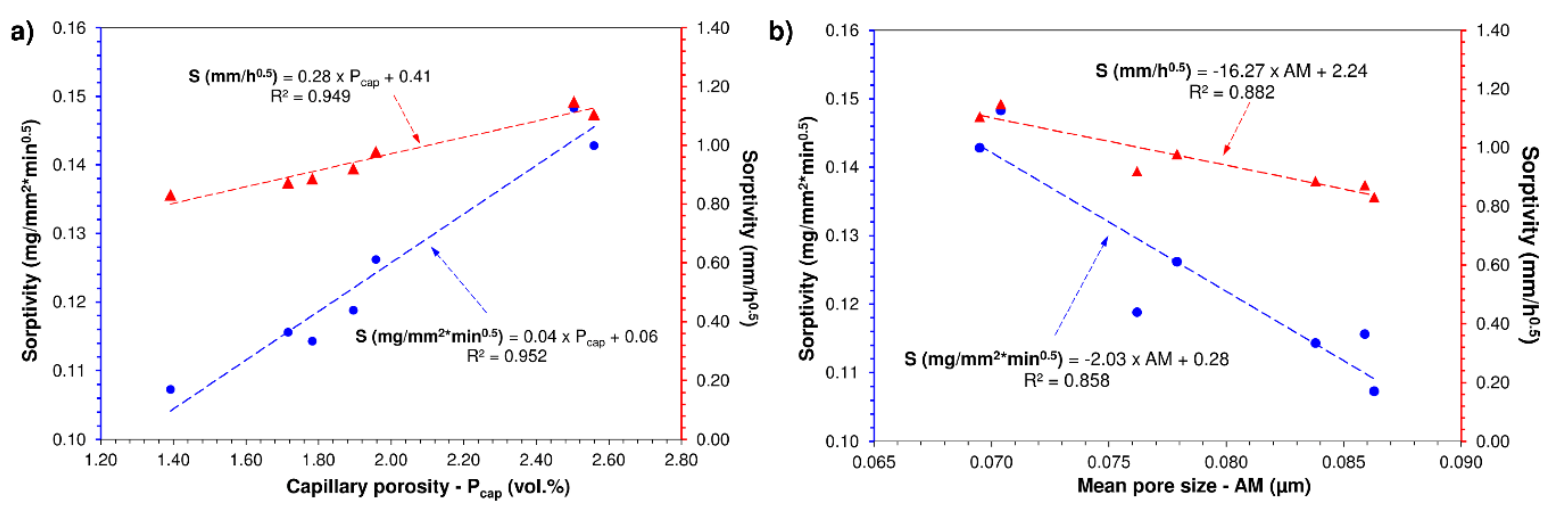

Figure 7. Correlation between pore system parameters and mortar sorptivity

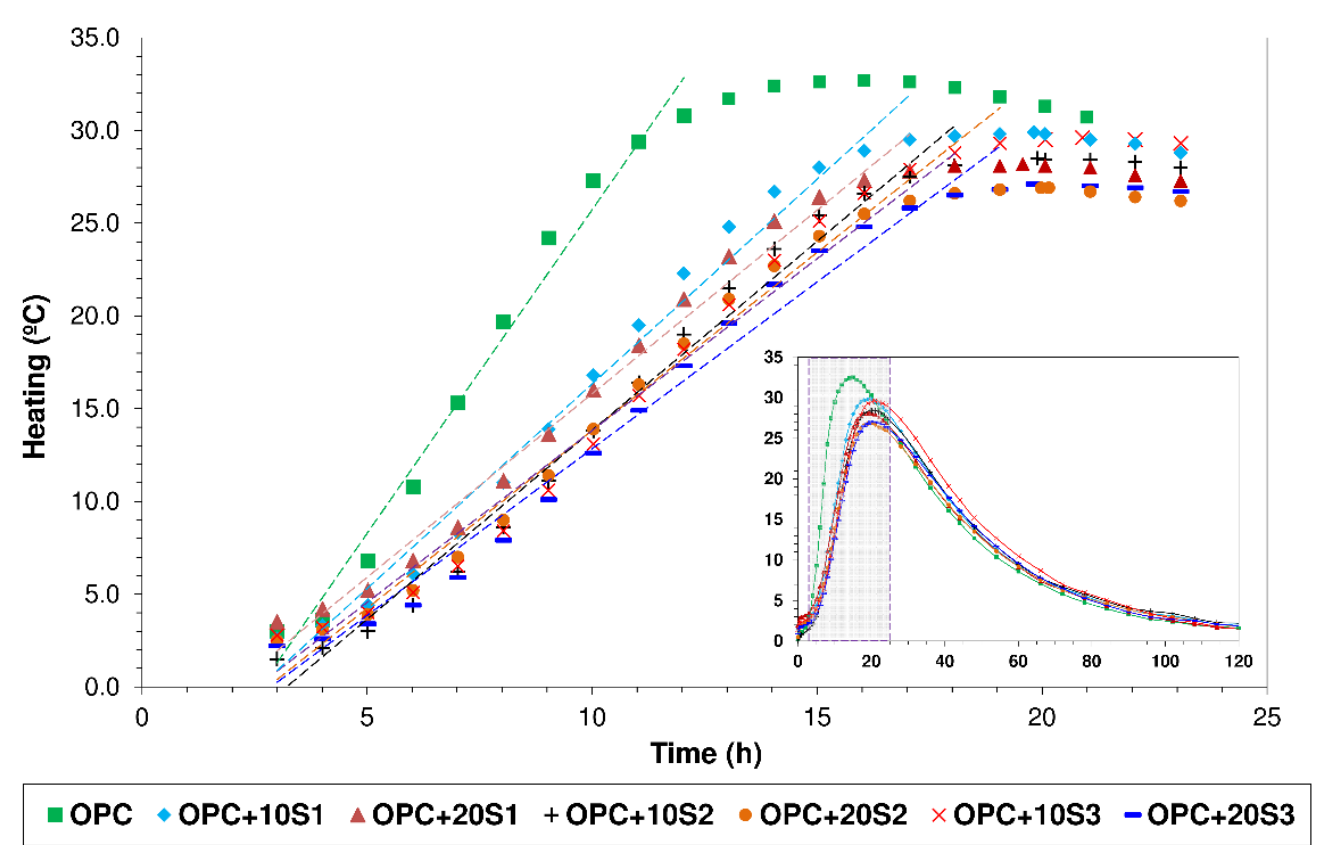

Figure 8. Mortar heating vs time from $3 \mathrm{~h}$ to $25 \mathrm{~h}$ 


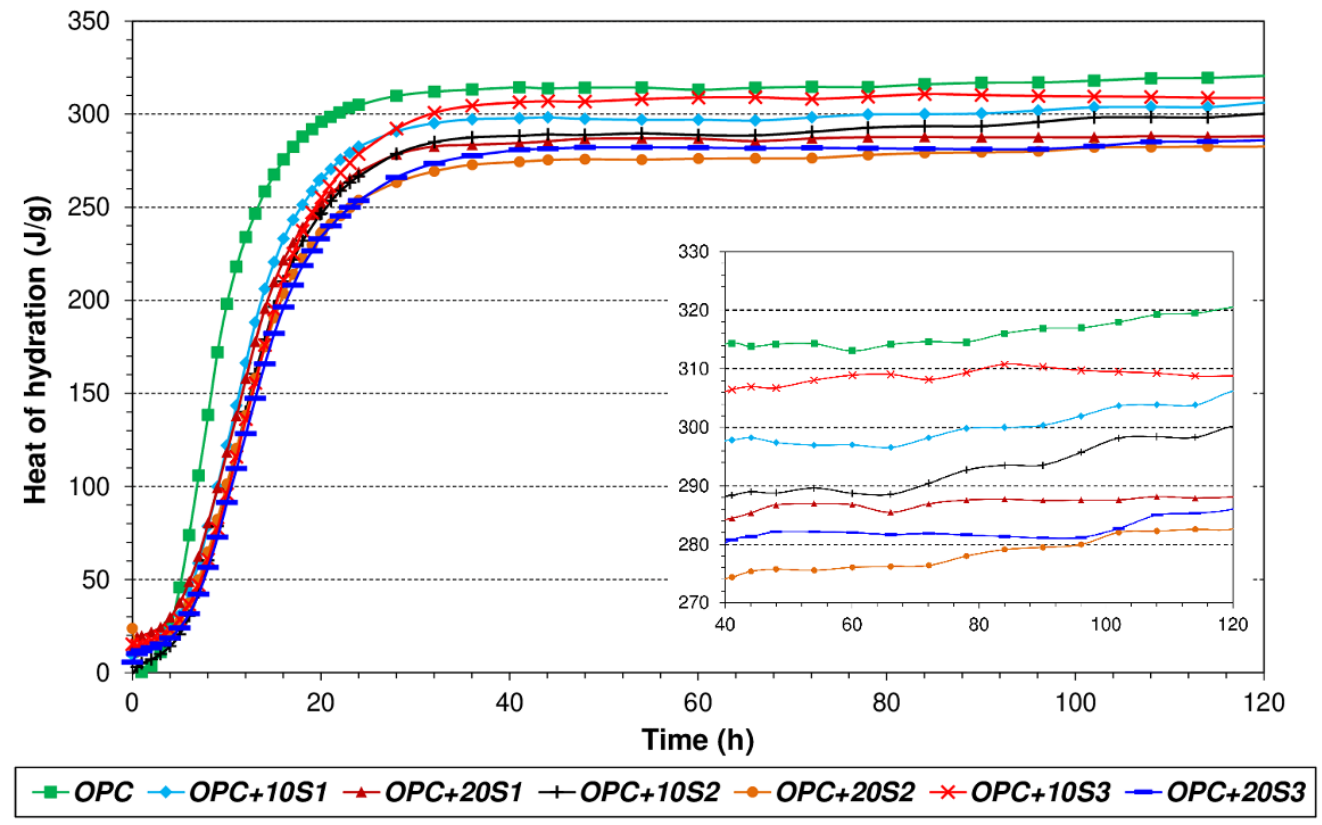

Figure 9. Total heat of hydration in mortars versus time 